\title{
THE ESTIMATION OF THE ORAL HYPOGLYCAEMIC AGENT CARBUTAMIDE IN BLOOD
}

\author{
BY \\ R. H. THOMPSON \\ From the Biochemical Laboratory, Royal Victoria Hospital, Belfast
}

(RECEIVED FOR PUBLICATION FEBRUARY 12, 1957)

Since the discovery that certain sulphonamide derivatives have a hypoglycaemic effect, interest has been stimulated in the search for newer compounds, and extensive clinical trials are being carried out into the effects of many of these in maintaining a normal blood sugar level in diabetics. Among the successful compounds $\mathrm{N}_{1}$-sulphanilyl- $\mathrm{N}_{2}$ - $\mathrm{n}$-butylcarbamide (BZ55, carbutamide) has been the one most extensively investigated.

In order fully to appraise the usefulness of this compound the search for an accurate method for the measurement of blood levels of carbutamide was proceeded with.

\section{Reagents}

The following reagents are required:

(1) Trichloroacetic Acid Solution, 15\% (w/v).

(2) Sodium Nitrite Solution, $0.1 \%(w / v)$. -This reagent should be made up fresh daily.

(3) Ammonium Sulphamate, $0.5 \%$ (w/v).

(4) N-(1-naphthyl)ethylenediamine Dihydrochloride, $0.5 \%(w / v)$. - This was kept in a brown bottle in the ice-chest.

(5) Stock Carbutamide Solution (0.1 mg./ml.).-For this reagent $0.1 \mathrm{~g}$. was dissolved in a few millilitres of $\mathrm{N}-\mathrm{NaOH}$ and diluted to $100 \mathrm{ml}$. with water.

(6) Working Carbutamide Solution $(1 \mu g . / m l$.$) .- One$ millilitre of the stock standard solution was transferred to a $100-\mathrm{ml}$. flask, $20 \mathrm{ml}$. of $15 \%$ trichloroacetic acid added, and the solution made up to the mark with distilled water.

\section{Methods}

Carbutamide has the structure

$$
\mathrm{H}_{2} \mathrm{~N}-\longrightarrow-\mathrm{SO}_{2} \cdot \mathrm{NH} \text {.CO.NH. }\left(\mathrm{CH}_{2}\right)_{3} \cdot \mathrm{CH}_{3}
$$

and so the free amino group is capable of diazotization and coupling, as in the case of other aromatic amines. Actually, the reaction described by Bratton and Marshall, involving coupling with $\mathrm{N}$-(1-naphthyl)ethylenediamine, seemed the most promising.
The following methods are the ones described:

Method A.-This was the method of Bratton and Marshall (1939) as modified by King (1951). In this technique $0.2 \mathrm{ml}$. blood was used, and deproteinization was performed by trichloroacetic acid at a final dilution of $1: 20$.

Method B.-This was similar to method A, but with deproteinization by trichloroacetic acid at a final dilution of $1: 40$.

Method C.-The Somogyi alkaline precipitant, $\mathrm{Zn}(\mathrm{OH})_{2}$, was used to deproteinize $0.1 \mathrm{ml}$. blood at a final dilution of 1:40. After appropriate acidification of the filtrate, diazotization and coupling were accomplished as in method A.

Method D.-The blood was deproteinized at a final dilution of $1: 100$, and a final concentration of trichloroacetic acid of $3 \%$. Since this is the method recommended, it is given here in full detail. This method is actually only a slight modification of that of Bratton and Marshall (1939).

Procedure.-Blood, $0.1 \mathrm{ml}$., was added to $7.9 \mathrm{ml}$. distilled water and the solution mixed in order to haemolyse the cells, $2 \mathrm{ml}$. of $15 \%$ trichloroacetic acid was added, the solution was mixed and centrifuged or filtered after a few minutes. Then $5 \mathrm{ml}$. of the filtrate was transferred to a test-tube, $0.5 \mathrm{ml}$. of $0.1 \%$ sodium nitrite solution added, and the mixture shaken and allowed to sit for three minutes. To the mixture $0.5 \mathrm{ml}$. of $0.5 \%$ ammonium sulphamate solution was added, mixed and allowed to sit for two minutes. Then $1 \mathrm{ml}$. of $0.5 \% \mathrm{~N}-(1-$ naphthyl)ethylenediamine solution was added and mixed. The colour was read in a photoelectric colorimeter after 15 minutes at $540 \mathrm{~m} i$, , setting to zero with a blank solution of $4 \mathrm{ml}$. of distilled water and $1 \mathrm{ml}$. of $15 \%$ trichloroacetic acid taken through the diazotization and coupling procedure.

A standard consisting of $5 \mathrm{ml}$. of the working standard solution was also taken through the same procedure.

Calculation.-Blood carbutamide (mg./100 ml.)

$$
\begin{aligned}
& =\frac{\text { Test reading }}{\text { Standard reading }} \times 0.005 \times \frac{100}{0.1} \times \frac{10}{5} \\
& =\frac{\text { Test reading }}{\text { Standard reading }} \times 10
\end{aligned}
$$




\section{Results}

Series of recoveries were carried out on the four methods, by adding amounts of carbutamide to the blood before deproteinizing, in order to give values corresponding to those in the first column (Table I). The results can be seen in the table in the respective columns.

TABLE I

RESULTS BY FOUR METHODS

\begin{tabular}{|c|c|c|c|c|}
\hline \multirow{2}{*}{$\begin{array}{c}\text { Final } \\
\text { Concentration } \\
\text { (mg./100 ml.) }\end{array}$} & \multicolumn{4}{|c|}{ Method (\% Recovery) } \\
\hline & $\mathbf{A}$ & B & C & $\mathbf{D}$ \\
\hline $\begin{array}{r}2.5 \\
5.0 \\
7.5 \\
10.0 \\
15.0 \\
20.0 \\
25.0\end{array}$ & $\begin{array}{l}73.4 \\
75.8 \\
78.3 \\
79.5 \\
= \\
= \\
\end{array}$ & $\begin{array}{l}\overline{77 \cdot 5} \\
\overline{81} \cdot 6 \\
86.7 \\
91 \cdot 7 \\
\end{array}$ & $\begin{array}{l}\overline{82} \cdot 1 \\
\overline{78} \cdot 0 \\
81 \cdot 8 \\
82 \cdot 4 \\
-\end{array}$ & $\begin{array}{r}95.6 \\
100.4 \\
100.6 \\
100.0 \\
98.6 \\
101.3 \\
98.7\end{array}$ \\
\hline
\end{tabular}

\section{Discussion}

The solubilities of sulphonamide compounds depend largely on the type of groupings masking the sulphonic group; in fact, it was along these lines that the most fruitful results were obtained in the search for new sulphonamides designed to exert their effect at specific sites in the body. Since carbutamide is less soluble the lower the $p \mathrm{H}$ of the medium, ranging from $9,570 \mathrm{mg} . / 100 \mathrm{ml}$. at $p \mathrm{H} 8$ to only $70 \mathrm{mg} / 100 \mathrm{ml}$. at $p \mathrm{H} 5$ (Achelis and Hardebeck, 1955), and if one postulates a binding of the free amino group to protein requiring a greater volume of acid to break it, then it is not surprising to find low recoveries of added carbutamide. By using higher ratios of trichloroacetic acid to protein greater $\bar{\partial}$ volumes of extracting fluid are available, leading $\stackrel{.}{\Rightarrow}$ to recoveries which are increased from approximately $77 \%$ at $1: 20$ dilution to $100 \%$ at $1: 100$ dilution.

Since the solubility of carbutamide is greater in $\frac{\bar{m}}{\overrightarrow{7}}$ alkaline solutions, it was expected that the $\mathbb{\mathbb { Q }}$ $\mathrm{Zn}(\mathrm{OH})_{2}$ deproteinization would be satisfactory. Although a constant recovery was found, allowing the use of a correction factor, this reagent is $\vec{\circ}$ not as good as trichloroacetic acid, because it $\overrightarrow{\vec{\omega}}$ involves the extra step of acidification before $\stackrel{\omega}{\sigma}$ diazotization.

\section{Summary}

Four variations of the Bratton and Marshall $\vec{\omega}$ method for estimation of carbutamide are com- \& pared. Poor recovery of carbutamide added to 을 blood in vitro is obtained using three common deproteinizing techniques, and conditions and $z$ details are given for quantitative recovery of carbutamide over the range 2.5 to $25 \mathrm{mg}$. $/ 100 \mathrm{ml}$. $\frac{\Phi}{3}$ blood, which is the range most likely to be met in clinical work.

I wish to thank Dr. J. A. Smyth for making availabse facilities and materials for this investigation. I a indebted to Mr. D. W. Neill for helpful criticism ant advice.

\section{REFERENCES}

Achelis, J. D., and Hardebeck, K. (1955), Dtsch. med. Wschr., 80, 1452.

Bratton, A. C., and Marshall, E. K. (1939). J. biol. Chem., 128, 537. $\overline{\overline{0}}$

King, E. J. (1951). Micro-analysis in Medical Biochemistry, 2nd ed., p. 27. Churchill, London. 